\title{
Teaching Information Management to Honors Degree Students: The Information Challenges Approach
}

\author{
Kevin Grant \\ Bell College \\ of Technology, Scot- \\ land \\ k.grant@bell.ac.uk
}

\author{
Mark Stansfield \\ University of Paisley, \\ Scotland \\ cio@wpmail.paislev.ac.uk
}

\author{
Ray Land \\ University of Edinburgh, \\ Scotland
}

\begin{abstract}
The aim of this paper is to provide an overview of what the authors believe to be a useful approach to teaching Information Management concepts and skills at honors (Hons) degree level. With Information Management being a somewhat diverse area, incorporating a number of areas and skills, one of the potential problems is considering how the subject can be taught to honors degree students in a flexible and meaningful way, while keeping abreast of new developments and thinking from academia and industry. The authors helped develop and deliver one possible approach to teaching Information Management at honors degree level that will be discussed in this paper, namely Information Challenges.
\end{abstract}

Keywords: Information management, information challenges, deep learning, transferable skills.

\section{Introduction}

Information Challenges forms part of the core modules that underpin the final year honors (Hons) component of the BA Business Information Management Degree at Napier University Business School in Edinburgh. A module is an assessed unit of study that is studied over a single semester, which in this case, make up a degree and honors degree course. In relation to employment opportunities, an honors degree sets students apart from those with an ordinary degree. An honors degree can significantly enhance students' career prospects by giving them the opportunity to demonstrate their potential and show initiative, as it tends to stretch the more able students in terms of their intellectual ability, planning ability and independent thought. The honors year also allows the students to develop in-depth knowledge via a dissertation in which they are provided with the opportunity to demonstrate their capability to work independently, set their own goals and develop research skills. Research opportunities to study for a M.Phil./Ph.D. in the United Kingdom specifically stipulate the students must have a good honors degree before they are considered for a research scholarship. In addition, many career opportunities in business and industry, particularly those aimed at working towards managerial posts, also look for students who have attained a good class of honors degree as part of their selection process.

The Scottish Higher Education sector tends to favor a four-year honors degree course and a three-year ordinary degree course as the norm of educational practice. The rationale for such a distinction is historical. However, within the context of the BA (Hons) Business Information Management degree at Napier University Business School, a four-year honors structure is necessitated by the incorporation of an industrial work experience element within the overall course design.

The degree program centers around the idea that information is a major resource of any enterprise and, effectively managed, it can yield significant business benefits both at an operational

Material published as part of this journal, either on-line or in print, is copyrighted by the publisher of Informing Science. Permission to make digital or paper copy of part or all of these works for personal or classroom use is granted without fee provided that the copies are not made or distributed for profit or commercial advantage AND that copies 1) bear this notice in full and 2) give the full citation on the first page. It is permissible to abstract these works so long as credit is given. To copy in all other cases or to republish or to post on a server or to redistribute to lists requires specific permission and payment of a fee. Contact Editor@inform.nu to request redistribution permission. 


\begin{tabular}{|c|c|c|c|}
\hline YEAR 1 & YEAR 2 & YEAR 3 (DEGREE) & YEAR 4 (HONORS) \\
\hline Information Systems & Business Systems Analysis & $\begin{array}{l}\text { Corporate Information } \\
\text { Systems }\end{array}$ & Information Challenges 1 \\
\hline Business in Context & $\begin{array}{l}\text { Human Issues in Business } \\
\text { Systems Analysis }\end{array}$ & $\begin{array}{l}\text { Corporate Information } \\
\text { Management }\end{array}$ & Information Challenges 2 \\
\hline Programming Concepts & Relational Database Systems & IT-Enabled Organizations & Honors Dissertation \\
\hline $\begin{array}{l}\text { Accounting for the } \\
\text { Business Environment }\end{array}$ & Systems Management & $\begin{array}{l}\text { Project Management for } \\
\text { Information Systems }\end{array}$ & $\begin{array}{l}\text { Two Business and } \\
\text { Information Management } \\
\text { option modules }\end{array}$ \\
\hline Marketing & $\begin{array}{l}\text { Introduction to } \\
\text { Information Management }\end{array}$ & Strategic Management & \\
\hline Behavioral Studies & & Work-based Learning & \\
\hline \multicolumn{4}{|l|}{ Quantitative Methods } \\
\hline Economics & & & \\
\hline
\end{tabular}

Table 1: The modules studied as part of the BA (Hons) Business Information Management degree course. and a strategic level. The course is underpinned by advances in Information Technology and Information Systems, together with a desire for organizations to achieve and sustain effective Information Management in terms of providing enhanced decision-making, communication and competitive advantage.

The range of modules offered to the students throughout the BA (Hons) Business Information Management degree course are shown in Table 1.

During the first year, students receive grounding in a range of business and information management related subjects as they progress through the degree program. Students can leave the course after the successful completion of year 3 with an ordinary degree in Business Information Management or they can stay on an extra year for an honors degree in Business Information Management.

The profile of an honors degree student ranges from a twentyone year old to a mature student in the thirties and beyond. The average age tends to be around the mid-late twenties. All the students have gained industrial work experience as part of the 12-week work-based learning module that they take in their degree year. Some of the students have held various positions in industry and commerce before coming to university.

\section{Problems with Teaching Information Management}

The challenge in teaching Information Management lies in presenting students with an academically rigorous subject matter that is both practical and relevant to those who will soon be practicing Information Managers. Some of the key areas considered appropriate for teaching on Information Management courses include technology, business and organisational issues (Earl \& Skyrme 1992), coupled with significant and relevant transferable skills. However, attaining suitable balance tends to be dependent upon individual course designers' preferences and what the host institution offers rather than the needs of today's Information Managers. It is essential however, that topical subject matter is incorporated which will capture the students' imaginations, while at the same time developing the important transferable skills essential to the modern Information Manager.

There is a view that the actual teaching of the theory relating to Information Management is not fully aligned with the actual practice of Information Management in commerce and industry. Galliers, Mylonopoulos, Morris \& Meadows (1997. p169) conclude that academics are either "indifferent or undecided with respect to the gap between researcher agendas and practitioner concerns". This necessitates the need to bridge the gap between research and teaching on the one side, and the 
needs of industry on the other through appropriate teaching vehicles and approaches.

\section{The Information Challenges Approach}

The term Information Challenges was coined to indicate the distinctive nature of the modules. The emphasis of the modules is on investigating current and future issues that graduates are likely to face when they become Information Managers, hence the Information element of the title. The Challenges component provides students with an academically rigorous approach to data collection, the synthesis of key ideas and the development of a creditable and sustainable line of argument.

Information Challenges is split into two parts. Information Challenges 1 provides students with more of an academic grounding within Information Management. This is particularly useful for students who are interested in pursuing a research or academic career in Information Management and wish to progress to a M.Phil./Ph.D. in the future. Information Challenges 2 is directed more at investigating Information Management from a commercial point of view, and is particularly directed at students who are interested in working within a business environment.

Information Challenges takes the form of a number of workshops spread over the academic year in which a topic or theme is introduced with a keynote address by an external guest speaker from industry or academia. Over an intensive period of four weeks, the students, working in teams, explore a number of relevant themes relating to the topic through a number of interactive workshop events. The workshop events are facilitated by the teaching team and comprise a mixture of structured tutorials, case-based investigations, laboratory-based work, directed reading, independent learning and open discussions.

At the end of the four-week period, each of the groups presents its views and findings through a plenary seminar to an audience of invited guests. In addition to presenting their views and findings, the students also face in-depth and intensive questioning from the audience. The session ends with an open discussion among all the participants in which particular points of interest are discussed more openly to facilitate further investigation and learning. At the end of the workshop events, the module teaching team reflects with the students upon the learning experiences that have taken place.

Examples of some of the areas explored within Information Challenges 1 included:
- linking together the hard and soft strands of systems thinking for information systems development,

- strategic information systems and competitive advantage,

- business process re-engineering - is it working?

Examples of some of the areas explored within Information Challenges 2 included:

- business benefits from the internet,

- justifying IT investment,

- future issues and areas of IT.

\section{Facilitating the Information Challenges Approach}

The Information Challenges approach is underpinned by a set of educational principles and values. These inform the design, delivery, assessment and evaluation of the program and are seen as essential to the achievement of the planned student learning outcomes. A range of specific teaching and learning strategies were influential in the design of the modules. For the purposes of this paper, the authors will focus on two main strategies, namely deep learning and transferable skills.

\section{Deep Learning}

The emphasis on interaction with peers is one component of the phenomenographic theory of learning developed by Säljö (1979), Entwistle \& Ramsden (1983) and Marton, Hounsell \& Entwistle (1984), and is more widely known as a deep learning approach. This has revealed two different approaches to learning in students: the surface approach and the deep approach.

In the surface approach, students tend to have a conception of learning as being fairly passive in terms of memorizing and reproducing. In the deep approach, students' learning is perceived as understanding, a way of making sense of the learning so that the students feel a sense of ownership of the knowledge and that they can explain it to another student. Learning is also viewed as personal development; students feel that the experience of learning has changed them in a personally meaningful fashion. It is more than just understanding what others mean; it has altered their way of seeing a particular aspect of reality. The learning is significant.

It is at this final stage that learning can become an absorbing and exciting process and when students can become genuinely enthused by it. The essence of a deep approach is that students are looking for the point of what is being learned, for links and relationships between ideas, and between ideas and the real 


\section{Teaching Information Management}

world. They identify relationships between their own previous understanding and experience. In doing this they do not just reproduce the knowledge, they actively engage with it, subsuming it within their own cognitive order or map. This kind of learning is essentially transformative.

To foster a deeper approach in students' learning within Information Challenges, an approach to teaching and learning was sought that would be likely to produce the following behaviors associated with a deep (transformative) approach.

\section{A vigorous and critical interaction with the content}

The students were actively encouraged by the teaching team to take a pro-active, student centered approach to their learning. Each student group had to argue and present its own particular view about the topic that had to be rigorously substantiated. Some very lively and interesting debates took place between the students and the teaching team. This provided an active learning environment in which some new and very interesting points concerning the topic and the themes explored were raised and reflected upon.

Therefore, the students were not simply interacting with the topics in a passive way that might be expected if a surface approach to learning was being adopted. The students were developing their understanding of the topics and shaping their views and opinions in a manner that was much more in keeping with a deep approach to learning. There were instances of students' learning experiences actually altering the way in which they viewed certain problem situations and undertook certain problem-solving tasks. Therefore, learning was becoming more transformative in nature.

\section{The relation of ideas to previous knowledge and experience}

Many of the topics explored within Information Challenges were based on previous knowledge and experiences that the students had been exposed to in earlier years of the degree course. The difference with exploring the topics through Information Challenges was that the students were exploring them in much more depth and they were shaping their views and opinions more. Thus, the emphasis was on depth of learning whereas previously the students may have only explored the topics through more of a surface approach to learning. In addition, the students were able to relate their experiences from the industrial work experience component of the degree course to certain topics and themes that they were exploring within Information Challenges.

\section{The relation of evidence to conclusions}

In developing their views and opinions about a topic, the students were expected to investigate and explore a wide range of materials that included journal papers, books, reports and case studies. Whilst the teaching team provided some material, the students were expected to provide their own evidence in support of their conclusions regarding a particular topic. Therefore, rather than being provided with the evidence, as might be expected with a more surface approach to learning, in which the role of the learner is to memorise facts, the students were adopting a more deeper approach to learning. The emphasis was on the students in collecting their evidence and relating it to justifying their views and opinions.

\section{Transferable Skills}

There has been a growing appreciation of the value of skills that will serve the student throughout life, rather than for a particular subject or job specification (Ellington, Percival \& Race, 1993). These skills, which include interpersonal skills, leadership skills, creative thinking, organisational skills, problem-formulation and problem-solving, are often referred to as transferable skills. The transferable skills that Information Challenges sought to develop in the students and that were also applicable to producing effective Information Managers for the future included the following.

\section{Effective communication skills}

During the course of Information Challenges, the students were able to develop their communication skills, in both oral and written form. At the end of each topic, each of the students had to present his or her findings to the rest of the class and invited guests, which included academics and practitioners in the area being explored. Therefore, the students had to be able to utilise presentation aids as well as be able to present their views in a clear, coherent and effective manner.

One of the assessment mechanisms used was that of producing a journal-style paper that formed the coursework element for Information Challenges 1 . The teaching team considered that by using the journal-style paper, the students were preparing themselves for careers as practicing Information Managers who should be capable of writing up their findings to a wider audience, in a clear, precise and professional format. Since Information Management is an evolving discipline, more practicing Information Managers are becoming involved in presenting their innovations and initiatives in the academic and business press. This assessment instrument was considered by the teaching team to be more conducive to the aims of Informa- 
tion Challenges by allowing the students to select the topic of their journal paper. This initiative gave the students the opportunity to study in greater depth a topic or theme which they were interested in.

Information Challenges 2 used a business report as part of its assessment instruments, which reflected the more practical and commercial orientation of the module. The students were presented with a business problem scenario and were asked to develop an Information Systems Strategy to take that organization into the 21 st Century. Thus, students were gaining experience in developing effective communication skills for both business and academic audiences.

\section{The ability to work with others}

In terms of developing their ability to work with others, since individual students could not assimilate all of the reading materials alone in exploring the topics, they had to work effectively as a group. Therefore, the students had to learn to collaborate with one another and work as a team in developing their views and exploring evidence to support these views. Within some groups a group leader or co-ordinator would emerge. Other groups would adopt a more democratic approach in which there was no clear leader. Although problems did arise with certain groups, such as personal differences arising and conflicts, the teaching team made it clear that it was the students' role to resolve any conflicts and problems. Thus, the students had to take responsibility for their actions and resolve any problems in ensuring that deadlines were met and all of the tasks completed. This is more akin to working in a business environment in which any personal differences between group members have to be addressed in order to ensure that important deadlines are met and that work is of the highest quality.

\section{The ability for creative problem-solving}

In terms of developing their ability for creative problemsolving, the students were encouraged to be creative in their exploration of the topics and themes. The interpretation of Information Management that has been developed within Information Challenges expects students to embrace the dynamic nature of Information Management and to cope with conflicting views and opinions. This helped the students to be more confident in their own judgements and decision-making abilities. In exploring different viewpoints, many students established links with businesses, political bodies and academic institutions in eliciting additional material to provide evidence to support their view of the topic and themes being explored.

\section{The Outcome of Information Challenges}

Clearly, the Information Challenges approach may not be suitable for all courses and subjects that are taught at honors degree level. Information Challenges should not be viewed as a substitute for more traditional teaching methods and courses. Any decision on whether to adopt an approach to teaching like Information Challenges is dependent upon the nature of the subject being taught, the aims and objectives of the particular course and the resources that are available to the teaching team.

The authors are not attempting to prove that Information Challenges is better than more traditionally run modules, but rather that it may be considered as an additional means of learning and teaching to be used in conjunction with more traditionally run modules that comprise a degree course. Therefore, it is exposing students to different forms of teaching that may broaden and build upon their learning experiences.

Feedback from the students suggests that they preferred the mini conferences as a means of learning about topics as opposed to learning a topic over the course of a semester. It is often the case that a number of students do not undertake the completion of assessments or revision for examinations until very close to the completion dates, which often has an adverse effect upon the quality of their work. This situation is often made worse if the completion dates are at the end of a semester since there is very little time for remedial work to be undertaken. In taking Information Challenges, the students were gaining formal feedback as to their progress from the teaching team throughout the semester, rather than at the end when they have completed their assessments. Since the student groups had to present their findings about a topic to the teaching team and invited audience every four weeks, they had to be better organised and prepared. In addition, the students faced intensive questioning from the audience as well as both oral and written feedback from the teaching team as to their progress and suggestions for improvement. Therefore, any remedial work that was necessary could be identified at key points throughout the semester, rather than problems being identified at the end of a semester.

The quality of the work produced by the different groups and the standard of answers to the questions posed did sometimes vary depending on the abilities and personalities that comprised a particular group. Where work was considered by the teaching team not to be of a high enough standard, extra sessions and guidance was given to particular students if they were experiencing difficulties. 


\section{Teaching Information Management}

Of the twenty honors degree students who comprised the first cohort to complete Information Challenges, two students were awarded first class honors degrees with another nine students being awarded higher second class honors degrees. Within six months of graduation all of the students had secured careers as Information Managers in a wide range of organizations, with three students securing posts as Management Consultants at two International Management Consultancy companies.

Clearly, there could be cases whereby students with poor academic performances achieve good positions within industry and commerce. However, feedback from employers, who interviewed and assessed the students' suitability for employment, was that they were impressed by their depth of knowledge of current issues relating to Information Management. In addition, they were impressed by their ability to justify points that they made, their resourcefulness in investigating relevant material as well as their well-developed communication skills. A measure of the success of Information Challenges has been that one International Management Consultancy company who employed graduates from the first cohort specifically asked the teaching team to recommend to them students from future cohorts for potential employment opportunities with them.

\section{Conclusion}

The authors have put forward Information Challenges as one possible means of providing honors degree students with deep learning experiences as well as further developing their transferable skills that may help them in their future careers. Information Challenges is not argued by the authors to be a wholly unique way of teaching and learning, since it draws upon a wide range of strategies already used throughout Higher Education.
For the teaching team, Information Challenges has presented an enriching learning experience in terms of developing their professional skills in teaching Information Management, as well as adapting and developing new and different ways of teaching than they had been used to. Information Challenges is flexible enough so that new themes within Information Management can be incorporated into the modules as well as new skills being introduced as the field develops and progresses. This means that students can be sure that they are receiving and developing highly relevant knowledge and skills that are being sought after in both industry and academia.

\section{References}

BA (Hons) Business Information Management Course Documentation, Department of Business Information Management, Napier University, June 1994.

Earl, M.J. \& Skyrme, D.J. (1992) Hybrid managers - what do we know about them? Journal of Information Systems, 2, 169-187.

Ellington, H., Percival, F. \& Race, P. (1993) A Handbook of Educational Technology. London: Kogan Page.

Entwistle, N. \& Ramsden, R. (1983) Understanding Student Learning. London: Croon Helm.

Galliers, R.D., Mylonopoulos, N.A., Morris, C. \& Meadows, M. (1997) IS research agendas and practices in the UK, In: Proc. 2nd UKAIS Conference, Avison, D.E. (ed), University of Southampton, 1997, 143-171.

Marton, F., Hounsell, D. \& Entwistle, N. (1984) The Experience of Learning. Scottish Academic Press.

Säljö, R. (1979) Learning about learning, Higher Education, 8, 443451. 